\title{
PENGARUH PROFITABILITAS, UKURAN PERUSAHAAN, DAN GOOD CORPORATE GOVERNANCE TERHADAP PENGUNGKAPAN CORPORATE SOSIAL RESPONSIBILTY DAN DAMPAKNYA TERHADAP ABNORMAL RETURN PADA PERUSAHAAN LQ45
}

\author{
Frisca Putri Kuncorowati' ${ }^{1)}$, Muhammad Miqdad ${ }^{2)}$, Ahmad Roziq ${ }^{3)}$ \\ ${ }^{1}$ Mahasiswa Magister Akuntansi Fakultas Ekonomi dan Bisnis, Universitas Jember, Indonesia \\ E-mail: friscap7@gmail.com \\ ${ }^{2}$ Magister Akuntansi Fakultas Ekonomi dan Bisnis, Universitas Jember, Indonesia \\ E-mail: miqdad.feb@unej.ac.id, \\ ${ }^{3}$ Magister Akuntansi, Fakultas Ekonomi dan Bisnis, Universitas Jember, Indonesia \\ E-mail: ahmadroziq.feb@unej.ac.id
}

\begin{abstract}
This study examines the effect of Profitability, Company Size, GCG on CSR disclosure and its impact on abnormal returns. The purpose of this study was to analyze the effect of Profitability, Company Size, GCG on abnormal returns and the indirect effect on CSR disclosure. The sample in this study was the LQ-45 company listed on the IDX in 2020. Data analysis used Path Analysis. The results of the path analysis study have directly shown that profitability, company size, GCG has a significant effect on CSRD with sig results less than 0.05. Meanwhile, the results of research using path analysis indirectly show that CSR disclosure is not able to strengthen the relationship between profitability, company size, GCG on abnormal returns.
\end{abstract}

Keyword: Profitability, Firm Size, GCG, CSR Disclosure, Abnormal Return

DOI: http://dx.doi.org/10.29040/jap.v22i1.1920

\section{PENDAHULUAN}

Pengambil keputusan yang dilakukan pemegang saham atau stakeholder harus memperhatikan beberapa hal untuk menunjang hasil keputusan investor, apabila stakeholder menganggap jika informasi yang diberikan perusahaan sebagai informasi yang bermanfaat maka memepngaruhi harga saham sehingga adanya tingkat kembalian yang tercermin dari abnormal return dan volume perdagangan saham (Lestari \& Subekti, 2002).

Pengambilan keputusan selain dipengaruhi oleh laba perusahaan yang tinggi, juga dapat dipengaruhi oleh pengungkapan sosial dan lingkungan (Guidry \& $\&$ Patten, 2010). Beberapa hasil penelitian menjelaskan bahwa adanya pengaruh pengungkapan tanggungjawab terhadap abnormal return dan volume perdaganagan saham yang disebabkan faktor kinerja keuangan, GCG dan factor lainnya (Dedman \& W-J, 2007) ; (Xu, 2011).

Kandungan informasi yang tepat dan akurat pada perusahaan sangat diperlukan oleh stakeholder sebagai penunjang keputusan investasi. Signal teori menjelaskan pengaruh dari kemampuan pasar yang efisien sebagai sinyal positif bagi stakeholder sebagai bagian dari pengambilan keputusan investasinya. Teori signalling menjelaskan adanya faktor eksternal seperti inflasi, bencana alam, kebijakan pemerintah, dan lainlain, serta faktor internal perusahaan seperti corporate action, pengungkapan kegiatan CSR, kebijakan manajemen, dan lain-lain memiliki pengaruh yang kuat dalam peningkatan harga perusahaan (Suganda, 2018).

Penentuan abnormal return ditentukan dengan nilai return yang diharapkan, nilai return sesungguhnya yang ditentukan dari nilai harga saham yang beredar. Kandungan informasi yang disampaikan oleh perusahaan diharapkan memberikan sinyal yang baik agar peningkatan harga shaam yang beredar tinggi, sehingga tingkat abnormal return yang didapatkan stakeholder semakin besar (Ratnawati \& Triyuwono, 2009).

Sebelum masuknya virus covid-19 di Indonesia, indeks LQ45 tumbuh sebesar 3,23\% pada akhir tahun 2019 (cnbcindonesia.com). Setelah masuknya covid-19 di Indonesia pada bulan februari 2020, beberapa saham yang tergabung dalam LQ 45 mengalami penurunan sebanyak $15 \%$. Hal tersebut jelas berdampak pada ekonomi Indonesia yang akan 
berpengaruh pada perdagangan saham, sehingga hal tersebut akan mempengaruhi reaksi investor dan mempengaruhi harga pasar yang ada di Bursa Efek Indonesia secara keseluruhan (Khoiriah;, 2020).

Salah satu aspek yang berpengaruh dalam pasar saham yaitu aspek kepercayaan investor. Aspek kepercayaan dapat ditunjukkan dari pengungkapan CSR, kinerja keuangan, serta baiknya tata kelola perusahaan. Adanya informasi perusahaan ditanggapi positif oleh investor dan stakeholder, pengungkapan informasi perusahaan diharapkan dapat memberikan signal serta dapat meningkatkan value added perusahaan bagi investor. Hal tersebut dapat menindikasikan bahwa informasi perusahaan yang melakukan pengungkapan akan direspon baik oleh investor sehingga mendapatkan profit dalam jangka panjang (Wijaya, 2005).

Pengungkapan CSR dilakukan perusahaan sebagai pembentukan, penguatan, serta penciptaan citra perusahaan agar dipandang memiliki itikad baik kepada masyarakat. Hal ini dapat diartikan jika pengungkapan CSR perusahaan dapat mempengaruhi eksistensi serta mempengerahui tingkat pengembalian tinggi yang dipengaruhi secara tidak langsung dari efek dilakukannya pengungkapan CSR (Iswanto, 2014). Perusahaan yang telah melakukan pengungkapan CSR akan memberikan banyak manfaat bagi perusahaan, secara tidak langsung perusahaan akan diminati para investor sehingga mempengaruhi abnormal return dari perusahaan tersebut.

Profitabilitas memiliki keterkaitan dengan penentuan pembagian abnormal return serta penetapan dalam pengungkapan CSR, dimana secara signifikan pengungkapan CSR memiliki pengaruh terhadap profitabilitas dan abnormal return. Semakin tinggi profitabilitas yang dihasilkan oleh perusahaan, berpengaruh terhdapa tingkat pengembalian yang besar, karena stakeholder beranggapan bahwa perusahaan yang memiliki itikad baik dalam pertanggungjawaban sosial memiliki sitra yang baik (Ahmed, Islam, \& Hasan., 2012).

ROE merupakan salah satu proksi profitabilitas yang digunakan dalam penelitian ini dimana ROE dapat mencerminkan hasil dari report kegiatan keuangan perusahaan, besarnya nilai ROE menentukan hasil pembagian tingakt pengembalian (abnormal retun) (Pratinah \& Kusuma., 2012). Pernyataan tersebut didukung oleh beberapa peneliti yang menyatakan bahwa adanya pengaruh antara ROE berpengaruh terhadap Abnormal return diantaranya (Natarsyah, 2000), (Raharjo, 2000), (Wibowo, 2003). Akan tetapi hasil penelitian lain menjelaskan bahwa tidak adanya hubungan antara ROE dengan Abnormal return, diantaranya (Linzzy P, 2015) dan (Abdullah, 2013).
ROE juga memiliki pengaruh pada pengungkapan CSR, hal ini sesuai dengan hasil penelitian seperti (Hartono \& dkk, 2011), (Anggara, 2010), (Rahmi Galuh, 2010), (Ni Nyoman, 2011) dan (Sari, 2012) menjelaskan jika ROE berpengaruh signifikan dan bernilai positif terhadap pengungkapan CSR. Sedangkan pada hasil penelitian (Kamil \& dkk, 2012) dan (Dewi \& \& Suaryana, 2015) menjelaskan bahwa ROE tidak memiliki pengaruh terhadap pengungkapan CSR.

Ukuran perusahaan salah satu variable penelitian yang sering dikaitkan dengan pengungkapan CSR dan penentuan rekasi investor yang direfleksikan dengan peningkatan pembagian return perusahaan. Ukuran perusahaan menjadi perhatian khusus oleh stakeholder karena ukuran perusahaan dalam kategori besar akan patuh dalam pengungkpan CSR. Hasil penelitiannya menjelaskan bahwa adanya hubungan positif dan signifikan antara ukuran perusahaan terhadap pengungkapan CSR. Hasil penelitiaan sebaliknya yang dilakukan oleh (Anggraini, 2006) dan (Oktariani, Putu, \& Harta, 2014) menemukan hasil bahwa ukuran perusahaan tidak mempengaruhi pengungkapan CSR.

Saham pada perusahaan kecil kurang diminati oleh pasaran ataupun investor sehingga perlu penentuan harga yang dapat menarik investor dengan tingkat pengembalian yang tinggi (Devi, 2010). Apabila ditinjau dari segi keamanan dan reputasi, Stakeholder dan investor akan lebih memilih perusahaan besar untuk menginvestasikan modalnya dibandingkan dengan perusahaan kecil, hal ini disebabkan karena perusahaan besar memberikan keyakinan kepada investor untuk mempercayakan dan menjaminkan tingkat kelangsungan usahanya dan kemungkinan kecil akan terjadi kerugian. Hasil penelitian (Daniatai dan Suhairi, 2010), dan (Devi, 2010) menjelaskan bahwa adanya hubungan positif dan signifikan antara ukuran perusahaan terhadap Abnormal return. Hasil penelitiaan sebaliknya yang dilakukan (Arikunto, 2004) menemukan hasil bahwa ukuran perusahaan tidak mempengaruhi Abnormal return.

GCG sebagai salah satu cara perusahaan untuk melindungi terhadap kepentingan stakeholder dan investor. Beberapa hasil penelitian membuktikan bahwa adanya pengaruh GCG terhadap pengungkapan CSR, diantaranya adalah (Wahyudi \& Pawestri, 2006), (Nurlela \& Islahuddin, 2008), (Haruman \& Tendi., 2008) yang menjelaskan terdapat hubungan signifikan dan bernilai positif antara GCG dengan pengungkapan CSR. Sebaliknya, hasil penelitian (Amran \& S. Susela, 2008), dan (Said \& Haron, 2009) yang menemukan hubungan negatif antara GCG dan pengungkapan CSR. Penerapan GCG pada perusahaan diharapkan dapat memperbaiki dan 


\section{Jurnal Akuntansi dan Pajak, 22(01), 2021, 80}

$\begin{array}{lcrr}\text { meningkatakan } & \text { monitoring } & \text { terhadap } & \text { kinerja } \\ \text { manajemen } & \text { perusahaan, } & \text { sehingga } & \text { dapat } \\ \text { meningkatnya } & \text { kinerja } & \text { keuangan } & \text { yang }\end{array}$ mempengaruhi value added perusahaan dan akan berdampak pada meningkatnya harga saham perusahaan (Kurnia S, 2012). (Sofilda dan Subaedi, 2006), (Pranata, 2007), (Wardani, 2008) menjelaskan bahwa terdapat pengaruh yang signifikan dan bernilai positif anatara GCG dengan abnormal return yang menggunakan proksi CGFI sebagai pengukuran kinerja GCG. Hasil lain ditunjukan oleh (Ujiyanto dan Pramuka, 2007) dan (Aprina, 2012) yang menjelaskan tidak adanya hubungan antara GCG dengan abnormal return.

Informasi akuntansi perusahaan dapat dikatakan memiliki nilai guna untuk investor dan stakeholder apabila informasi dapat memberikan reaksi untuk melakukan transaksi di pasar modal. Beberapa penelitian telah melakukan penelitian terhadap pengujian ROE, ukuran perusahaan, GCG, terhadap abnormal return melalui hubungan pengungkapan CSR. (Nurdin \& Cahyandito, 2006), (Nuzula \& Kato, 2010), dan (Hendarto \& Purwanto, 2012) menjelaskan bahwa pengungkpana CSR berhubungan erat dengan pengaruh ROE, ukuran perusahaan dan GCG yang diproksikan dengan kepemilikan manajemen terhadap abnormal return yang menyatakan terdapat hubungan signifikan dan bernilai positif. Hasil penelitian tersebut berbeda dengan penelitian yang dilakukan oleh (Hillman \& Keim, 2001), (Reddy \& Gordon, 2010) yang menjelaskan bahwa pengungkapan CSR memiliki hubungan negatif dengan pengaruh ROE, ukuran perusahaan, GCG terhadap abnormal return.

Penulis menggunakan beberapa teori untuk memperkuat hasil penelitian dan hipotesis, diantara yaitu teori legitimasi yang berkaitan dengan metode pengelolaan kinerja perusahaan yang berorientasi pada stakeholder dan investor. Teori stakeholder lebih mengedepankan kepada pihak-pihak yang harus dipertanggungjawabkan oleh perusahaan. Teori signalling menjelaskan bahwa semua informasi perusahaan memberikan sinyal baik oleh investor, maka perusahaan akan terdorong untuk menyampaikan "good news" kepada calon investor, dengan upaya dapat meningkatkan tingkat pengembalian (abnormal return) yang tinggi.

Peneliti tertarik untuk menggunakan data analisis dari perusahaan LQ45 sebagai objek penelitian, karena saham emitem yang masuk dalam indeks LQ45 merupakan saham unggulan (frekuensi, volume,dan nilai kapitalisasi tinggi) dan aktif,serta terkategori dalam blue chip yang diminati stakeholder dan investor dalam memutuskan investasi saham di BEI. Proksi yang digunakan dalam penelitian ini diantarnya adalah kinerja keuangan diproksikan dengan ROE, karakteristik perusahaan diproksikan dengan ukuran perusahaan, GCG diproksikan dengan CGPI, Pengungkapan CSR diproksikan dengan GRI, dan reaksi pasar diproksikan dengan abnormal return. 1.1 Teori Legitimasi

Teori legitimasi menjelaskan adanya hubungan antara perusahaan dengan masyarakat terkait aktivitas sosial perusahaan, dimana dibutuhkan adanya tujuan perusahaan yang selaras dengan nilai- nilai yang berkembang dimasyrakat dan sesuai aturan UU yang sudah ditetapkan. Teori ini menjelaskan bahwa seluruh aktivitas dan kinerja perusahaan harus dapat diterima oleh masyarakt. Perusahaan akan memperoleh legitimasi yang baik dari masyarakat apabila nilai-nilai yang ditanamkan dalam kegiatan perusahaan sejalan dengan aturan masyarakat (Ratmono, 2015).

Teori legitimasi menerangkan jika pengungkapan informasi terkait kinerja, sosial yang dilakukan perusahaan adalah cara untuk mendapatkan legitimasi dari masyarakat dan stakeholder. Legitimasi yang diperoleh perusahaan menyebabkan perusahaan terhindar dari kejadian yang tidak diharapkan dan menambah value adde bagi perusahaan, dan secara tidak lagsung akan mempengaruhi tingkat keuntungan perusahaan. Teori ini menegaskan bahwa perusahaan tidak hanya memperhatikan hak-hak perusahaan dan stakeholder akan tetapi hak masyarakat juga wajib diperhatikan (Ratmono, 2015).

\subsection{Teori Sinyal}

Teori Sinyal berakar pada teori akuntansi pragmatik yang memusatkan perhatiannya kepada pengaruh informasi terhadap pergantian sikap pemakai data. Salah satu data akuntansi biasanya dijadikan sinyal oleh investor sebagai hasil pengungkapan informasi oleh emiten. Pengungkapan data ini nantinya bisa memegaruhi naik turunnya harga sekuritas industri emiten tersebut. Pengungkapan data akuntansi bisa mengirimkan sinyal positif jika industri memiliki prospek yang baik ( good news) ataupun kebalikannya sinyal kurang baik( bad news) di masa mendatang (Guthrie \& dkk, 2004)

Teori sinyal menekankan berartinya data yang dikeluarkan oleh industri terhadap keputusan investasi pihak di luar industri. Data akuntansi adalah salah satu faktor fundamental untuk investor serta pemnagku kepentingan,sebab data pada hakekatnya menyajikan penjelasan, catatan ataupun cerminan baik buruknya kondisi masalalu dan akan datang pada perusahaan yang mempengaruhi kelangsungan hidup dan efek pasar saham terhadap perusahaan. Data akuntansi yang lengkap, relevan, akurat, transparan, dan just in time sangat dibutuhkan oleh investor di pasar modal sebagai perlengkapan analisis untuk pengambilan keputusan investasi (Guthrie \& dkk, 2004). 


\subsection{Teori Stakeholder}

Tujuan dari teori stakeholder adalah melakukan pengelolaan perusahaan secara efektif dan membantu manajer untuk memahami pentingnya memberikan perhatian lebih pada hal-hal diluar non keuangan. Tujuan lain dari teori ini adalah, manajer dapat meningkatakan value added perusahaan akibat dampak dari aktivitas perusahaan serta dapat meminimalkan kerugian bagi perusahaan dan stakeholder. Dapat disimpulkan, jika teori ini menjelaskan bahwa adanya hubungan erat antara stakeholder dengan perusahaan dalam menjalankan kerjasama mereka (Rokhlinasari, 2006).

Eksistensi perusahaan ditentukan dengan adanya peran stakeholder. Informasi pengungkapan yang tertuang dalam laporan keuangan dan tahunan digunakan sebagai dialog antara manajemen dan stakeholder (Indrawati, 2009). Aktivitas perusahaan sangat erat hubungannya dengan lingkungan dan masyarakat, maka pengungkapan informasi memiliki peran penting bagi perusahaan karean perusahaan hidup dalam lingkungan masyarakat yang mana segala aktivitasnya berdampak pada lingkungan dan sosial. Pengungkapan informasi akuntansi ini diharapkan dapat memenuhi kebutuhan stakeholder sebagai salah satu alasan dalam pengemabilan kebijakan. Dengan demikian, perusahaan akan mendapatkan dukungan stakeholder yang berpengaruh terhadap kelangsungan hidup perusahaan (Sembiring E. R., 2005).

\subsection{Profitabilitas}

Profitabilitas merupakan hasil kebijakan dan keputusan manajemen perusahaan tentang keuntungan perusahaan (Brigrham \& Houston, 2009). Dapat disimpulkan bahwa profitabilitas perusahaan merupakan kemampuan untuk menghasilkan laba bersih dari aktivitas perusahaan dalam periode akuntansi. Perusahaan yang memiliki tingkat pengembalian tinggi atas investasi pada perusahaan yang memperoleh laba yang besar, dapat dikatakan perusahaan tersebut memiliki kinerja yang baik, dan begitu sebaliknya. Manajer perusahaan harus mempunyai kebijakan atas laba yang diperoleh perusahaan dengan peningkatan penjualan dan meminimalisir biaya yang dikeluarkan. Hal ini dikarenakan laba sebagai ukuran kinerja perusahaan harus dilakukan evaluasi dan dibandingkan setiap periodenya agar diketahui tingkat kenaikan laba perusahaan setaip tahunnya.

ROE (return On Equity) merupakan salah satu proksi profitabilitas yang biasa digunakan oleh stakeholder untuk meliat kondisi perusahaan, dimana manajeme perusahaan lebih bebas dan fleksibel dalam pengungkapan informasi kuangan dan non keuangan kepada pemegang saham
(Sembiring E. , 2006), sehingga dapat disimpulkan bahwa ROE merupakan kemampuan perusahaan untuk mendapatkan laba untuk meningkatkan harga saham perusahaan. ROE adalah hasil yang diperoleh dari laba setelah pajak dengan menggunakan modal sendiri yang dimiliki perusahaan. ROE diperlukan oleh pihak pemegang saham untuk menegtahui efektivitas dan efisiensi dalam pengelolaan modal utama perusahaan yang sesuai dengan kebijakan yang dilakukan oleh manajemen (Prasetyorini, 2013).

\subsection{Ukuran Perusahaan}

Ukuran perusahaan merupakan pengukuran perusahaan yang dilihat dari total asset perusahaan pada akhir tahun. Total perusahaan digunakan untuk mengukur perusahaan, karena biaya yang terkait dengan penggunaan asset cenderung lebih besar, sehingga perusahaan dengan ukuran perusahaan yang besar dan dengan tingkat asset yang dimiliki lebih tinggi akan memilih kebijakan akuntansi yang dapat mengurangi laba (Sidharta, 2000).

Penelitian ini mengukur ukuran perusahaan menggunakan logaritma natural dari total asset. Hal ini dikarenakan karena proksi total asset lebih menggambarkan keadaan perusahaan, pernyataan ini didukung oleh hasil penelitian (Agus, 2007), dalam penelitiannya menggunakan ukuran perusahaan sebagai penilaian karakteristik perusahaan.yang dalam penelitiannya menggunakan pula variabel ukuran perusahaan. Hasil penelitian menjelaskan bahwa proksi tersebut dapat mempengaruhi pengungkapan informasi (Agus, 2007).

\subsection{Good Corporate Governance \\ GCG (Good Corporate Governance)} merupaka peraturan yang mengatur hubungan anatara pemegang saham, pengelola atau pengurus perusahaan, stakeholder (yaitu pihak kreditur, pemerintah, karywana) serta pemegang kepentingan internal dan eksternal yang berkaitan erat dengan hak dan kewajiban pemangku kepentingan, atau dapat diartikan bahwa sistem yang mengendalikan perusahaan. Adanya GCG dalam perusahaan bertujuan agar menciptakan value added perusahaan bagi stakeholder (Hindarmojo, 2002). Penerapan GCG sangat bermanfaat untuk perusahaan dalam jangka panjang yaitu sebagai pendukung dari tumbuh kembangnya perusahaan di era persaingan global, selain itu juga dapat meningkatkan nilai tambah perusahaan dalam meningkatkan kinerja untuk menghadapi persaingan usaha yang semakin kompetitif (Amin W, 2013:39). Penilaian prinsip GCG perusahaan, menggunakan proses penilaian skoring yang disebut dengan selfassessment checklist yang dikembangkan oleh 
FCGI. Penilaian diberikan pada lima bidang secara objektif yaitu hak pemegang saham, kebijakan corporate governance, praktik corporate governance, pengungkapan, dan fungsi audit (Naja, 2004).

\subsection{Pengungkapan CSR}

Pengungkapan CSR adalah cara perusahaan untuk menyampaikan informasi dan pertanggungjawaban sosial dari perusahaan terhadap stakeholder (Nuswandari, 2009). Pengungkapan ini sebagai salah satu cara untuk mendapatkan, mempertahankan seta meningkatkan legitimasi kepada stakeholder. Pengungkapan informasi dalam laporan tahunan menjadi dua yaitu pengungkapan wajib (mandatory disclosure) dan pengungkapan sukarela (voluntary dislclosure). Pengungkapan CSR menjadi penilaian kinerja perusahaan atas praktik pertanggungjawaban perusahaan yang terdiri dari kinerja ekonomi, sosial, dan lingkungan.

Pengungkapan CSR dihitung dengan menggunakan content analysis yang bersumber dari data sekunder. Analisis isi digambarkan sebagai suatu teknik penelitian untuk tujuan sistematika dan deskriptif kuantitatif suatu manifestasi jawaban komunikasi (Khaira Amalia Fachrudin, 2011). Perusahaan wajib melakukan pengungkapan CSR secara mandatory disclosure, dan dilaporkan dalam laporan tahunana seperti yang diatur dalam UU No. 40 Tahun 2007 tentang Perseroan Terbatas pasal 66 ayat (2).

Acuan yang dipakai dalam melakukan analisis isi adalah pedoman indikator kinerja GRI G4. Pertimbangan pemakaian alat analisis tersebut adalah supaya informasi yang diperoleh memiliki mutu yang baik secara kuantitas maupun kualitasnya. Hal tersebut terkait dengan seberapa besar perusahaan memiliki kepedulian terhadap pengungkapan CSR. Hasil yang diperoleh dari penggunaan analisis konten adalah berupa beberapa indikator yang representatif untuk mengukur tingkat keluasan pengungkapan CSR (Khaira Amalia Fachrudin, 2011).

\subsection{Abnormal Return}

Abnormal return dapat diartikan kelebihan dari tingkat pengembalian return sesungguhnya terhadap return normal. Return normal merupakan return yang diharapkan oleh investor (return ekspektasi). Dapat disimpulkan bahwa abnormal return adalah selisih antara return sesungguhnya (actual return) yang terjadi dengan return ekspektasi (expected return) (Jogiyanto, 2009). Perbandingan antara selisih abnormal return periode sekarang dan sebelumnya adalah tingkat keuntungan yang sesungguhnya.Abnormal return ini akan dihitung dengan selisih antara expected return dan actual return, dimana expected return dihitung dengan return pasar yang dikalikan dengan beta masing-masing perusahaan ditambah dengan alpha masing-masing perusahaan. Sedangkan, actual return merupakan perbandingan harga saham hari hari ini dengan harga saham sebelumnya secara relatif. Abnormal return akan diperoleh oleh pemegang saham setelah adanya peristiwa tertentu, hal ini berakibat pada abnormal return yang diperoleh bernilai negatif karena actual return yang diperoleh lebih rendah dibanding expected return (Kornel, 2016).

\subsection{Pengembangan Hipotesis}

ROE adalah proksi yang digunakan untuk mengukur profitabiltas. ROE digunakan melihat kemampuan dari modal sendiri untuk menghasilkan keuntungan bagi seluruh kepentingan pemegang saham baik saham biasa dan saham preferen. Besarnya nilai ROE akan menarik minat investor untuk menanamkan modalnya pada perusahaan karena dapat mengindikasikan perusahaan memiliki kinerja yang baik dan akibatnya akan meningkatkan pengembalian abnormal return. Menurut (Ratri, 2011) profitabilitas berpengaruh signifikan dan positif terhadap abnormal return, sesuai dengan pendapat (Saleh,2015), (Kohansal et al,2013), (Wang et al,2013). Terkait penelitian diatas ROE dengan Abnormal return, maka hipotesis yang diajukan dalam penelitian ini adalah:

\section{$\mathrm{H}_{1}$ : Profitabilitas berpengaruh terhadap Abnormal return}

Pengaruh profitabiltas dan citra perusahaan terhadap pengungkapan CSR menunjukkan bahwa adanya pengaruh dalam kinerja keuangan berupa profitabiltas yang dikeluarkan perusahaaan terhadap setiap pengungkapan CSR. Jika tingkat pengembalian modal sendiri meningkat maka akan mempengaruhi tingginya pengungkapan CSR, begitu juga jika tingkat pengembalian modal sendiri menurun maka akan mempengaruhi turnunya pengungkapan. Hasil penelitian ini sejalan dengan penelitian yang dilakukan oleh (Kamaludin,2010), (Wardhani,2007), (Kurnianto,2011) menjelaskan bahwa dalam hasil penelitiannya jika ROE berpengaruh signifikan dan bernilai positif terhadap pengungkapan CSR. Hasil penelitian mengenai hubungan profitabiltas dan pengungkapan CSR perusahaan dengan hasil yang positif, telah dibuktikan oleh (O'Dowyer, 2003), (Rashid \& Ibrahim, 2002), (Baron, 2005) dan (Anggraini, 2006), maka hipotesis yang diajukan dalam penelitian ini adalah:

\section{$\mathrm{H}_{2}$ : Profitabilitas berpengaruh terhadap pengungkapan CSR.}

Ukuran perusahan adalah variable yang umum digunakan untuk mengukur dan menjelaskan mengenai pengungkapan perusahaan dalam laporan tahunan 
perusahaan. Perusahaan besar merupakan emiten yang dipandang publik sehingga perusahaan melakukan pengungkapan yang lebih besar untuk mengurangai biaya politis sebagai perwujudan tanggung jawab sosial perusahaan (Sembiring E. , 2006). Hasil penelitian sebelumnya menunjukkan bahwa ukuran perusahaan berpengaruh positif terhadap pengungkapan CSR (Amalia, 2013), (Aslan \& Sigal, 2016), (Branco \& Rodrigues, 2008), (Chan,Watson,\& Woodliff, 2014), (Kristi,2012), (Purwanto, 2011), (Reverte, 2009), (Sari, 2012), dan (Solikhah \& Winarsih 2016). Berdasarkan penelitian-penelitian tersebut, maka hipotesis yang diajukan dalam penelitian ini, yaitu:

\section{$\mathrm{H}_{3}$ : Ukuran perusahaan berpengaruh terhadap} pengungkapan CSR.

Ukuran perusahaan menjelaskan tentang skala perusahaan dengan melihat besar kecilnya suatu perusahaan. variable ini dapat diukur melalui total aktiva yang dimiliki oleh perusahaan, hasil penjualan, serta jumlah modal. Pengukuran ukuran perusahaan dalam penelitian ini menggunakan total aktiva saham yang dimiliki perusahaan kecil kurang diminati oleh investor sehingga membutuhkan penentuan harga sesuai dengan harga pasar agar investor memperoleh hasil yang memberikan abnormal return lebih tinggi secara signifikan (Devi, 2010). Hasil penelitian diatas diperkuat dengan hasil beberapa penelitian berikut (Ulfa, 2011), (Prince et al., 2014), (Daniati dan Suhairi, 2006) dan (Absari, 2010) menunjukan bahwa ukuran perusahaan berpengaruh signifikan terhadap abnormal return. Berdasarkan penelitian-penelitian tersebut, maka hipotesis yang diajukan dalam penelitian ini, yaitu:

\section{$\mathrm{H}_{4}$ : Ukuran perusahaan berpengaruh terhadap Abnormal Return.}

Salah satu tujuan GCG adalah mendorong adanya kesadaran untuk bertanggungjawab atas aktivitas operasional perusahaan terhadap masyarakat dan kelestarian lingkungan di sekitar perusahaan sehingga dapat terjadinya kesinambungan usaha dalam jangka panjang. (Dwi \& Diah, 2014). Pelaksanaan GCG yang baik pada perusahaan ditandai dengan adanya pengungkapan CSR sebagai wujud kepedulian perusahaan pada lingkungan sosial (Nina \& Barus, 2016). Pernyataan diatas diperkuat dengan hasil penelitian terdahulu yang melakukan penelitian adanya pengaruh positif GCG terhadap pengungkapan CSR yaitu (Nasir \& Abdullah, 2004), (Rosmasita, 2007). Berdasarkan asumsi teresebut, maka hipotesis yang dapat dirumuskan adalah:

\section{$\mathrm{H}_{5}$ : Good Corporate Governance berpengaruh terhadap pengungkapan CSR.}

Penerapan GCG pada perusahaan diharapkan dapat memperbaiki dan meningkatkan pengawasan terhadap kinerja manajemen suatu perusahaan, sehingga meningkatkan kinerja perusahaan yang berdampak pada reaksi pasar (Kurnia S, 2012). Hasil penelitian ini sejalan dengan singnaling theory yang menjelaskan bahwa informasi yang dipublikasikan sebagai pengumuman (good news) oleh perusahaan akan memberikan sinyal bagi investor dalam pengambilan keputusan investasi. Hasil penelitian ini diperkuat dengan hasil penelitian terdahulu diantaranya (Sofilda dan Subaedi, 2006), (Pranata, 2007), (Wardani, 2008) menjelaskan adanya pengaruh positif dan signifikan antara GCG dengan Abnormal return yang menggunakan indeks CGFI sebagai pengukuran kinerja GCG. Berdasarkan pernyataan teresebut, maka hipotesis yang dapat dirumuskan adalah:

\section{$\mathrm{H}_{6}$ : Good Corporate Governance berpengaruh} terhadap Abnormal return.

Informasi perusahaan dianggap sebagai good news oleh stakeholder dan investor karena informasi yang disajikan memberikan informasi tentang keadaan perusahaan baik dari kinerja keuangan, karakteristik perusahaan, serta GCG perusahaan. Perusahaan dengan keadaan kinerja kuangan yang baik, karakteristik perusahaan yang memadai, serta GCG yang tertib akan memberikan sinyal yang bagus untuk investor serta dapat memberikan peluang besar bagi investor untuk memperoleh laba bersih yang tinggi dari setiap modal yang diinvestasikan sehingga akan direspon positif oleh pasar yang tercermin dalam abnormal return (Astuti, 2015).

Penelitian terdahulu yang mendukung adanya pengaruh profitabiltas, ukuran perusahaan, GCG, melalui pengungkapan CSR terhadap abnormal return adalah (Baron, 2005), (Rute \& Crowther, 2005). (Raar, 2004) menjelaskan bahwa profitabiltas, ukuran perusahaan, GCG memiliki hubungan erat terhadap abnormal return, dimana hal ini berpengaruh dalam pengambilaan kebijakan perusahaan untuk meningkatkan citra perusahaan dan menciptakan kesejahteraan baik bagi perusahaan maupun investor. Berdasarkan penelitian-penelitian tersebut, maka hipotesis yang diajukan dalam penelitian ini, yaitu:

$\mathrm{H}_{7}$ : Profitabiltas, Ukuran Perusahaan, GCG, melalui pengungkapan CSR berpengaruh terhadap abnormal return

Kerangka konseptual terdiri dari variabel dependen diantaranya kinerja keuangan yang diproksikan dengan ROE, karakteristik perusahaan yang diproksikan dengan ukuran perusahaan, dan GCG yang diproksikan dengan metode scoring FCGI dan independent diantaranya pengungkapan CSR yang diproksikan dengan GRI G4, serta reaksi investor diproksikan dengan abnormal return. Sehingga kerangka konseptual dapat digambarkan yakni sebagai berikut: 


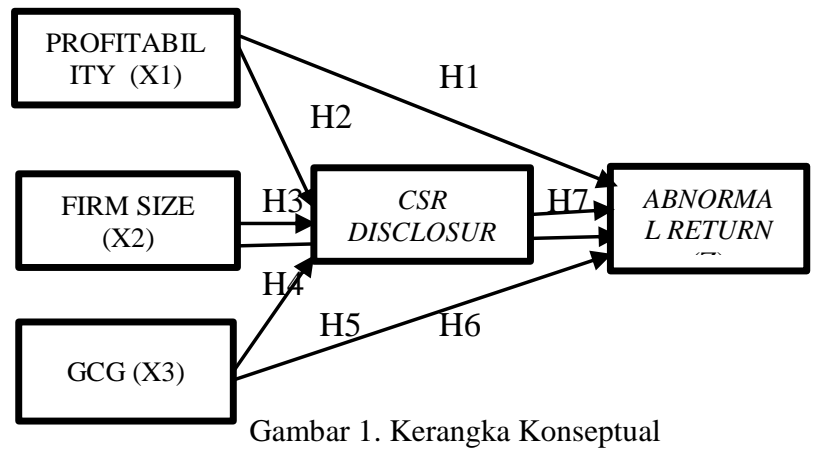

\section{METODE PENELITIAN}

Jenis penelitian yang digunakan adalah penelitian explanatory research dengan pendekatan yaitu kuantitatif. Metode explanatory research merupakan metode penelitian yang bermaksud menjelaskan kedudukan variabel-variabel yang diteliti serta pengaruh antara satu variabel dengan variabel yang lain (Sugiyono, 2016). Populasi penelitian ini adalah seluruh perusahaan yang terdaftar dalam BEI. Sampel yang digunakan dalam penelitian ini adalah perusahaan indek LQ45 yang terdaftar di Bursa Efek Indonesia.

Jenis data yang digunakan dalam penelitian ini adalah data sekunder yang berupa annual report dan laporan CSR dengan pengukuran GRI G4 serta data CGPI Perusahaan pada tahun 2020, yang diperoleh dari data annual report yang tersedia di IDX (Indonesian Stock Exchanges) tahun 2020. Data yamg diperoleh untuk abnormal return diantaranya: 1) Tanggal pengumuman saham bonus setiap perusahaan yang digunakan sebagai event date (t0). 2) Jumlah saham yang diperdagangkan secara harian, 3) Jumlah saham yang beredar atau listed share, 4) Abnormal return dan IHSG (Indek Harga Saham Gabungan) harian.

Metode pengumpulan data yang digunakan yaitu dengan cara studi dokumentasi, yaitu merupakan suatu cara yang digunakan untuk memperoleh data berupa laporan tahunan yang telah dipublikasikan oleh perusahaan sampel pada periode tahun 2020 di website BEI (www.idx.co.id). Tahapan dalam analisis data penelitian ini yaitu, melaksanakan pengujian analisis statistik deskriptif, analisis asumsi klasik, dan analisis statistic inferensial.

\section{HASIL DAN PEMBAHASAN}

\subsection{Hasil penelitian}

Analisis inferensial adalah variabel yang digunakan untuk menganalisis data sampel dan hasilnya diberlakukan untuk populasi yang jelas dan variabel pengambilan sampel dari populasi itu dilakukan secara random. Dalam penelitian ini peneliti menggunakan alat analisis yaitu analisis jalur (path analysis), dengan tujuan menerangkan pengaruh langsung atau tidak langsung antar variabel eksogen dengan variabel endogen.

Analisis Jalur (Langsung)

Metode analisis data dalam penelitian ini adalah analisis jalur (path analysis) dengan SPSS Versi 22 untuk mengetahui hubungan variabel dependen yaitu CSR dan abnormal return dengan variabel independen (ROE, Ukuran Perusahaan, GCG). Dan hubungan antara variabel mediasi (CSR) dengan variabel dependen yaitu abnormal return. Kriteria pengujian dengan tingkat kepercayaan $95 \%$ atau taraf signifikansi $5 \% \quad(\alpha=0,05)$. Analisis Pengaruh Langsung dilakukan dengan model regresi berganda dengan tujuan ingin menguji pengaruh dari variabel eksogen terhadap variabel endogen. Hasil dari analisis dapat dilihat dari gambar dibawah ini:

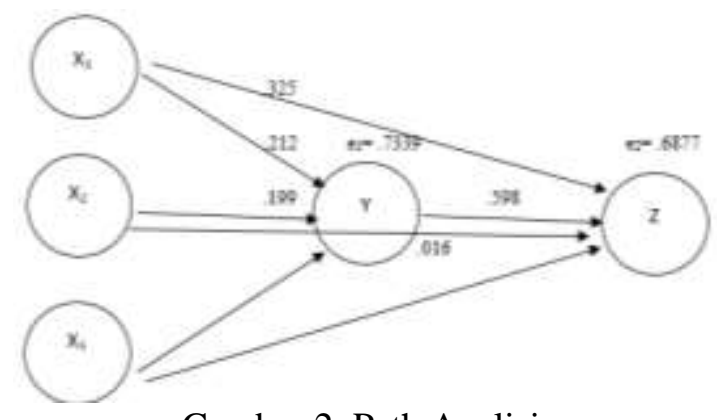

Gambar 2. Path Analisis

Dari hasil analisis jalur diatas maka dapat disimpulkan bahwa ada 2 tahap alur yang dikerjakan yaitu koefisien jalur model I dan koefisien jalur model II. Berikut penjelas dari kedua model tersebut adalah:

Koefisien jalur model I: mengacu dari hasil outpu regresi model I pada bagian table coefficients dapat diketahui bahwa nilai signifikan dari ketiga variable yaitu $X_{1}=.000, X_{2}=.000, X_{3}=.000$ lebih kecil dari 0.05 . Hasil ini menyimpulkan bahwa regresi model I, yaitu variable $X_{1}, X_{2}$, dan $X_{3}$ berpengaruh signifikan terhadap Y. Besarnya nilai $\mathrm{R}$ Squer yang terdapat pada table model summary adalah .401, hal ini menunjukkan bahwa adanya kontribusi pengaruh pada variable $\mathrm{X}_{1} \mathrm{X}_{2}$, dan $\mathrm{X}_{3}$ terhadap $\mathrm{Y}$ adalah $40.1 \%$, sementara sisanya $59.9 \%$ merupakan kontribusi dari variablevariable lain yang tidak terkait dalam penelitian. Untuk nilai $\mathrm{e}_{1}$ dapat dicari dengan rumus $\mathrm{e}_{1}=\sqrt{ }(1-0.401)=$ $\sqrt{ } 0.599=0.7339$.

Koefisien jalur model II: mengacu dari hasil outpu regresi model II pada bagian table coefficients dapat diketahui bahwa nilai signifikan dari ketiga variable yaitu $\mathrm{X}_{1}=.008, \mathrm{X}_{2}=.019, \mathrm{X}_{3}=.036$, dan $\mathrm{X}_{4}=.000$ lebih kecil dari 0.05 . Hasil ini menyimpulkan bahwa regresi model II, yaitu variable $\mathrm{X}_{1}, \mathrm{X}_{2}, \mathrm{X}_{3}$ dan $\mathrm{X}_{4}$ berpengaruh signifikan terhadap $\mathrm{Y}$. Besarnya nilai $\mathrm{R}$ Squer yang terdapat pada table model summary adalah .527 , hal ini 
menunjukkan bahwa adanya kontribusi pengaruh pada variable $\mathrm{X}_{1}, \mathrm{X}_{2}, \mathrm{X}_{3}$ dan $\mathrm{X}_{4}$ terhadap $\mathrm{Y}$ adalah $52.7 \%$, sementara sisanya $47.3 \%$ merupakan kontribusi dari variable- variable lain yang tidak terkait dalam penelitian. Untuk nilai $\mathrm{e}_{2}$ dapat dicari dengan rumus $\mathrm{e}_{2}=\sqrt{ }(1-0.527)=\sqrt{ } 0.473=0.6877$.

Berdasarkan persamaan struktural dari analisis jalur, Profitabilitas (X1); Ukuran Perusahaan (X2); GCG (X3); berpengaruh terhadap Abnormal return (Z) melalui CSR (Y) secara simultan dan signifikan. Berikut hasil uji hipotesis yang dapat disimpulkan yaitu

1) Hipotesis 1 (H1) menyatakan bahwa profitabilitas berpengaruh signifikan terhadap Abnormal Return. Gambar 2 menunjukkan hasil pengujian dengan nilai Standardized Coefficients Beta sebesar 0.325 dan signifikansi pada tabel 4.6 sebesar $0.008<0.05$ $(\alpha=0,05)$. Nilai Standardized Coefficients Beta yang positif dan signifikansi yang lebih dari 0,05 membuktikan bahwa ada pengaruh antara profitabilitas dengan Abnormal Return, maka pernyataan hipotesis 1 diterima.

2) Hipotesis $2(\mathrm{H} 2)$ menyatakan bahwa profitabilitas berpengaruh signifikan terhadap pengungkapan CSR. Gambar 2 menunjukkan hasil pengujian dengan nilai Standardized Coefficients Beta sebesar 0.212 dan signifikansi pada tabel 4.6 sebesar 0.000 $<0.05(\alpha=0,05)$. Nilai Standardized Coefficients Beta yang positif dan signifikansi yang lebih dari 0,05 membuktikan bahwa ada pengaruh antara profitabilitas dengan CSR, maka pernyataan hipotesis 2 diterima

3) Hipotesis 3 (H3) menyatakan bahwa Ukuran Perusahaan berpengaruh signifikan terhadap pengungkapan CSR. Gambar 2 menunjukkan hasil pengujian dengan nilai Standardized Coefficients Beta sebesar 0.016 dan signifikansi pada tabel 4.6 sebesar $0.000<0.05(\alpha=0,05)$. Nilai Standardized Coefficients Beta yang positif dan signifikansi yang lebih dari 0,05 membuktikan bahwa ada pengaruh antara Ukuran Perusahaan dengan CSR, maka pernyataan hipotesis 3 diterima

4) Hipotesis 4 (H4) menyatakan bahwa Ukuran Perusahaan berpengaruh signifikan terhadap Abnormal Return. Gambar 2 menunjukkan hasil pengujian dengan nilai Standardized Coefficients Beta sebesar 0.016 dan signifikansi pada tabel 4.6 sebesar $0.019<0.05(\alpha=0,05)$. Nilai Standardized Coefficients Beta yang positif dan signifikansi yang lebih dari 0,05 membuktikan bahwa ada pengaruh antara ukuran perusahaan dengan Abnormal Return, maka pernyataan hipotesis 4 diterima.

5) Hipotesis 5 (H5) menyatakan bahwa GCG berpengaruh signifikan terhadap pengungkapan CSR. Gambar 2 menunjukkan hasil pengujian dengan nilai Standardized Coefficients Beta sebesar
0.172 dan signifikansi pada tabel 4.6 sebesar 0.000 $<0.05(\alpha=0,05)$. Nilai Standardized Coefficients Beta yang positif dan signifikansi yang lebih dari 0,05 membuktikan bahwa ada pengaruh antara GCG dengan CSR, maka pernyataan hipotesis 5 diterima

6) Hipotesis 6 (H6) menyatakan bahwa GCG berpengaruh signifikan terhadap Abnormal Return. Gambar 2 menunjukkan hasil pengujian dengan nilai Standardized Coefficients Beta sebesar 0.206 dan signifikansi pada tabel 4.6 sebesar $0.036<0.05$ $(\alpha=0,05)$. Nilai Standardized Coefficients Beta yang positif dan signifikansi yang lebih dari 0,05 membuktikan bahwa ada pengaruh antara GCG dengan Abnormal Return, maka pernyataan hipotesis 6 diterima

Analisis Sobel (Pengaruh Tidak Langsung)

Adanya pengaruh tidak langsung dapat menentukan pola hubungan antara tiga atau lebih variabel yang digunakan menguji kausalitas hubungan variabel. Hasil analisis jalur untuk variable ROE, Ukuran perusahaan, dan GCG dapat disimpulkan sebagai berikut:

1) Analisis pengaruh profitabilitas melalui pengungkapan CSR terhadap Abnormal return menunjukkan bahwa Abnormal return dapat berpengaruh langsung terhadap profitabilitas dan dapat juga berpengaruh tidak langsung yaitu dari profitabilitas ke pengungkapan CSR (sebagai mediasi) lalu ke Abnormal Return. Besarnya pengaruh langsung adalah 0.325 sedangkan besarnya pengaruh tidak langsung harus dihitung dengan mengalikan koefisien tidak langsungnya yaitu $(0.212) \times(0.598)=0.1268$ atau total pengaruh profitabilitas ke Abnormal return $=$ $0.325+(0.212) \times(0.598)=0.4518$

Pengaruh mediasi yang ditunjukkan oleh perkalian koefisien ( $\mathrm{p} 1 \mathrm{x}$ p7) sebesar 0.1658 signifikan atau tidak, diuji dengan sobel test sebagai berikut:

$$
\begin{aligned}
& \mathrm{S}_{\mathrm{ab}}=\sqrt{b^{2} S a^{2}+a^{2} S b^{2}+S a^{2} S b^{2}} \\
& \mathrm{~S}_{\mathrm{ab}}= \\
& \sqrt{(0.598)^{2} \times(0.148)^{2}+(0.212)^{2} \times(0.158)^{2}+(0.158)^{2} \times(0.148)^{2}} \\
& \mathrm{~S}_{\mathrm{ab}}=\sqrt{0.0078+0.0011+0.000576} \\
& \mathrm{~S}_{\mathrm{ab}}=\sqrt{0.009476} \\
& \mathrm{~S}_{\mathrm{ab}}=0.09
\end{aligned}
$$

Berdasarkan hasil $\mathrm{S}_{\mathrm{ab}}$, peneliti dapat menghitung nilai t hitung memiliki pengaruh mediasi dengan rumus berikut

$\mathrm{T}_{\text {hitung }}=\frac{a b}{\mathrm{Sab}}$

$\mathrm{T}_{\text {hitung }}=\frac{(0.212) x(0.598)}{0.09}$

$\mathrm{T}_{\text {hitung }}=1.408$

Dapat disimpulkan, jika nilai $\mathrm{t}$ hitung= 1.408 lebih kecil dari $\mathrm{t}$ tabel dengan tingkat 
signifikansi 0.05 yaitu sebesar 2.021. Berdasarkan hasil perhitungan diatas diperoleh nilai pengaruh langsung sebesar 0.325 dan pengaruh tidak langsung sebesar 0.1268 yang berarti bahwa nilai pengaruh profitabilitas secara langsung lebih berpengaruh daripada nilai profitabilitas melalui pengungkapan CSR yang mempunyai pengaruh pada abnormal return.

2) Analisis pengaruh ukuran perusahaan melalui pengungkapan CSR terhadap Abnormal return menunjukkan bahwa Abnormal return dapat berpengaruh langsung terhadap ROE dan dapat juga berpengaruh tidak langsung yaitu dari ukuran perusahaan ke CSR (sebagai mediasi) lalu ke Abnormal Return. Besarnya pengaruh langsung adalah 0.016 sedangkan besarnya pengaruh tidak langsung harus dihitung dengan mengalikan koefisien tidak langsungnya yaitu (0.199) $\mathrm{x}$ $(0.598)=0.1190$ atau total pengaruh ukuran perusahaan ke Abnormal return $=0.016+(0.199)$ $\mathrm{x}(0.598)=0.135$

Pengaruh mediasi yang ditunjukkan oleh perkalian koefisien ( $\mathrm{p} 1 \mathrm{x}$ p7) sebesar 0.1823 signifikan atau tidak, diuji dengan sobel test sebagai berikut:

$\mathrm{S}_{\mathrm{ab}}=\sqrt{b^{2} S a^{2}+a^{2} S b^{2}+S a^{2} S b^{2}}$

$\mathrm{S}_{\mathrm{ab}}=$

$\sqrt{(0.598)^{2} x(0.165)^{2}+(0.199)^{2} x(0.158)^{2}+(0.158)^{2} x(0.165)^{2}}$

$\mathrm{S}_{\mathrm{ab}}=\sqrt{0.0094+0.00098+0.00067}$

$\mathrm{S}_{\mathrm{ab}}=\sqrt{0.011}$

$\mathrm{S}_{\mathrm{ab}}=0.104$

Berdasarkan hasil $S_{a b}$, peneliti dapat menghitung nilai t hitung memiliki pengaruh mediasi dengan rumus berikut

$\mathrm{T}_{\text {hitung }}=\frac{a b}{\mathrm{Sab}}$

$\mathrm{T}_{\text {hitung }}=\frac{(0.199) x(0.598)}{0.104}$

$\mathrm{T}_{\text {hitung }}=1.144$

Dapat disimpulkan, jika nilai $\mathrm{t}$ hitung= 1.144 lebih kecil dari $\mathrm{t}$ tabel dengan tingkat signifikansi 0.05 yaitu sebesar 2.021. Berdasarkan hasil perhitungan diatas diperoleh nilai pengaruh langsung sebesar 0.016 dan pengaruh tidak langsung sebesar 0.1190 yang berarti bahwa nilai pengaruh profitabilitas secara tidak langsung lebih berpengaruh daripada nilai profitabilitas berpengaruh pada abnormal return. Hasil ini menunjukkan bahwa perhitungan menggunakan nilai beta variable ukuran perusaahan memiliki pengaruh tidak langsung, akan tetapi jika menggunakan penghitungan $\mathrm{t}$ hitung, ukuran perusahaan lebih berpengaruh langsung pada abnormal return daripada melalui pengungkapan CSR sebagai variable mediasi.

3) Analisis pengaruh GCG melalui pengungkapan CSR terhadap Abnormal return menunjukkan bahwa Abnormal return dapat berpengaruh langsung terhadap GCG dan dapat juga berpengaruh tidak langsung yaitu dari GCG ke pengungkapan CSR (sebagai mediasi) lalu ke Abnormal Return. Besarnya pengaruh langsung adalah 0.206 sedangkan besarnya pengaruh tidak langsung harus dihitung dengan mengalikan koefisien tidak langsungnya yaitu (0.172) $\mathrm{x}$ $(0.598)=0.1028$ atau total pengaruh GCG ke Abnormal return $=0.206+(0.172) \times(0.598)=$ 0.3088

Pengaruh mediasi yang ditunjukkan oleh perkalian koefisien ( $\mathrm{p} 1 \mathrm{x}$ p7) sebesar 0.0545 signifikan atau tidak, diuji dengan sobel test sebagai berikut:

$\mathrm{S}_{\mathrm{ab}}=\sqrt{b^{2} S a^{2}+a^{2} S b^{2}+S a^{2} S b^{2}}$
$\mathrm{~S}_{\mathrm{ab}}=$
$\sqrt{(0.598)^{2} x(0.137)^{2}+(0.172)^{2} x(0.158)^{2}+(0.158)^{2} x(0.137)^{2}}$
$\mathrm{~S}_{\mathrm{ab}}=\sqrt{0.00073+0.0065+0.00046}$
$\mathrm{~S}_{\mathrm{ab}}=\sqrt{0.00769}$
$\mathrm{~S}_{\mathrm{ab}}=0.09$

Berdasarkan hasil $S_{\mathrm{ab}}$, peneliti dapat menghitung nilai t hitung memiliki pengaruh mediasi dengan rumus berikut

$\mathrm{T}_{\text {hitung }}=\frac{a b}{\mathrm{Sab}}$

$\mathrm{T}_{\text {hitung }}=\frac{(0.172) x(0.598)}{0.09}$

$\mathrm{T}_{\text {hitung }}=1.129$

Dapat disimpulkan, jika nilai $\mathrm{t}$ hitung= 1.129 lebih kecil dari $t$ tabel dengan tingkat signifikansi 0.05 yaitu sebesar 2.021. Berdasarkan hasil perhitungan diatas diperoleh nilai pengaruh langsung sebesar 0.206 dan pengaruh tidak langsung sebesar 0.1028 yang berarti bahwa nilai pengaruh GCG secara langsung lebih berpengaruh daripada nilai GCG melalui pengungkapan CSR yang mempunyai pengaruh pada abnormal return. Dari data diatas, maka untuk hipotesis 7 (H7) menyatakan bahwa profitabilitas dengan nilai thitung 1.408, Ukuran Perusahaan dengan nilai thitung 1.144, GCG dengan nilai thitung 1.129 melalui pengungkapan CSR terhadap abnormal return lebih berpengaruh secara langsung. Hal ini disebabkan karena nilai thitung lebih kecil dari $\mathrm{t}$ table yaitu 2.021.

\subsection{Pembahasan}

\section{Pengaruh profitabilitas terhadap Abnormal Return}

Jika profitabiltas semakin tinggi maka perusahaan dapat menghasilkan keuntungan bersih setelah pajak dari modal sendiri yang dapat menguntungkan pemegang saham. Besar kecilnya nilai profitabiltas akan mempengaruhi abnormal return perusahaan. Semakin tinggi nilai profitabiltas, akan menarik minat para investor untuk menanamkan 
modalnya pada perusahaan bersangkutan karena mengindikasikan bahwa perusahaan tersebut mempunyai kinerja yang baik dan akibatnya abnormal return pun akan ikut tinggi. Dapat disimpulkan bahwa profitabiltas yang tinggi mengindikasikan abnormal return yang tinggi dan ketika profitabiltas rendah mengindikasikan abnormal return yang rendah. Investor tertarik menjadikan ROE sebagai salah satu alasan untuk investor menanamkan modal diperusahaan. Penelitian yang dilakukan oleh (Cholidia,2017) menjelaskan bahwa investor cenderung menggunakan analisis kinerja keuangan dalam pengambilan keputusannya dalam berinvestasi, menunjukkan bahwa faktor ROE mengambil peranan penting dalam pengambilan keputusan investasi

Hasil penelitian ini didukung dengan hasil penelitian (Ratri, 2011) Return on Equity (ROE) berpengaruh signifikan dan positif terhadap harga saham, sesuai dengan pendapat (Saleh,2015), (Kohansal et al,2013), (Wang et al,2013). ROE merupakan rasio penting bagi para pemilik dan pemegang saham karena rasio tersebut menunjukkan kemampuan perusahaan dalam mengelola modal dari pemegang saham untuk mendapatkan laba bersih. Perusahaan yang memiliki ROE yang rendah atau bahkan negatif akan terklasifikasikan sebagai perusahaan yang kurang baik dalam menghasilkan laba yang menjadi hak pemegang saham (Lestari,Lutfi \& Syahyunan,2007: 5).

\section{Pengaruh profitabiltas terhadap Pengungkapan CSR}

Rasio profitabilitas sebagai hasil akhir bersih dari berbagai kebijakan keputusan yang dilakukan perusahaan, rasio ini digunakan sebagai alat pengukur atas kemampuan perusahaan untuk memperoleh keuntungan. Terlaksananya tugas agen kepada prinsipal yaitu mendapatkan profit akan memberikan kebebasan kepada manajemen perusahaan untuk melakukan CSR yang juga merupakan langkah untuk menjaga korelasi baik dengan stakeholders (Pradnyani dan Sisdyani, 2015). Profitabilitas merupakan salah satu faktor yang dapat mempengaruhi pengungkapan CSR (Sari \& Puspita, 2015). Pengungkapan digunakan oleh para manajer perusahaan kepada para investor dan untuk membantu mendukung keberlanjutan dan kompensasi manajemen. ROE tinggi menunjukkan kinerja perusahaan yang baik, dan dengan laba yang tinggi perusahaan memiliki dana untuk mengumpulkan, mengelompokkan, dan mengolah informasi menjadi lebih bermanfaat serta dapat menyajikan pengungkapan yang lebih komprehensif. Semakin tinggi profitabilitas perusahaan maka akan semakin tinggi kelengkapan pengungkapan laporan tahunan (Dibiyantoro, 2011). Penelitian ini konsisten dengan penelitian (Mulyadi \& Anwar, 2012),
(Pradnyani \& Sisdyani, 2015) serta (Purba \& Yadnya, 2015) yang menyatakan bahwa profitabilitas yang diukur dengan return on equity (ROE) berpengaruh terhadap pengungkapan CSR. Sari (2012) menyatakan bahwa rasio profitabilitas dapat mengukur kemampuan eksekutif perusahaan dalam menciptakan tingkat keuntungan baik dalam bentuk laba perusahaan maupun nilai ekonomis atas penjualan, aset bersih perusahaan ataupun modal sendiri (shareholders equity).

\section{Pengaruh Ukuran Perusahaan terhadap Pengungkapan CSR}

(Sari \& Puspita, 2015) menjelaskan bahwa ukuran perusahaan dapat digunakan sebagai salah satu faktor yang mempengaruhi pengungkapan CSR. Ukuran perusahaan merupakan skala yang berfungsi untuk mengklasifikasikan besar kecilnya perusahaan. Secara umum, perusahaan besar akan mengungkapkan informasi sosial atau tanggung jawab sosial lebih banyak dari pada perusahaan kecil. Hal ini dapat dijelaskan secara teoritis bahwa perusahaan besar merupakan entitas bisnis yang tidak lepas dari resiko tekanan politis yang lebih besar dibandingkan perusahaan kecil. Perusahaan besar yang memerlukan tingkat pengungkapan yang lebih luas karena perusahaan besar memiliki tingkat penjualan besar, kualitas kemampuan karyawan yang baik, sistem informasi yang canggih, nilai aktiva yang besar dan banyaknya jenis produk. Tekanan politis ialah tekanan untuk entitas bisnis yang banyak disoroti oleh masyarakat luas agar lebih mengungkapkan tanggungjawab sosial (CSR) atas aktivitas usahanya terhadap lingkungan sekitarnya. (Sari \& Puspita, 2015).

Pengaruh ukuran perusahaan terhadap pengungkapan CSR tercermin dalam teori legitimasi yang menjelaskan bahwa perusahaan besar mempunyai tingkat legalitas yang tinggi serta tanggungjawab yang besar kepada masyarakat, sehingga pengungkapkan informasi akan lebih banyak dibanding perusahaan kecil (Subiantoro \& Mildawati, 2015). Ukuran perusahaan dapat diukur pada total aktiva, volume penjualan, jumlah tenaga kerja, dan kapitalisasi pasar. Secara teoritis perusahaan besar tidak akan lepas dari tekanan, dan perusahaan yang berukuran besar akan memiliki karakteristik yaitu aktivitas operasionalnya, memiliki dampak lebih besar terhadap masyarakat, sehingga perusahaan akan melaksanakan tanggung jawab sosialnya untuk menghindari konflik dengan masyarakat di perusahaan itu beroperasi (Urmila \& Mertha, 2017). Hasil penelitian ini didukung oleh hasil penelitian yang dilakukan oleh (Rindawati \& Asyik, 2015), (Bangun, Andhika, \& Wijaya, 2016) dan (Kusumadewi \& Suaryana, 2014). Tetapi, hasil penelitian dari (Maiyarni, Susfayetti, \& Erwati,2014) 
dan (Widya \&Sandra, 2014) menyatakan bahwa ukuran perusahaan tidak memiliki pengaruh terhadap pengungkapan CSR.

\section{Pengaruh Ukuran Perusahaan terhadap Abnormal Return}

Ukuran perusahaan (firm size) merupakan total dari aktiva yang dimiliki oleh perusahaan yang dapat dilihat dari neraca. Sekuritas perusahaan kecil kurang dapat dipasarkan sehingga membutuhkan penentuan harga sedemikian rupa agar investor memperoleh hasil yang lebih tinggi secara signifikan (Devi,2010). Ukuran perusahaan merupakan salah satu dari faktor yang mempengaruhi tingkat return saham. (Raida,2010) menjelaskan jika tingkat return saham dipengaruhi oleh salah satu faktor karakteristik perusahaan yang dapat dihitung dari ukuran perusahaan. Jika dilihat dari segi keamanan dan prestise, investor akan lebih memilih perusahaan besar untuk menanamkan dana dan modalnya dibandingkan perusahaan kecil, karena perusahaan besar memberikan keyakinan kepada calon investor atas tingkat kelangsungan hidup usahanya agar lebih terjamin dan sangat kecil kemungkinan jika terjadi kerugian dalam menanamkan modalnya daripada di perusahaankecil. Sehingga dapat disimoulkan jika semakin banyak investor yang menanamkan modalnya pada saham perusahaan besar maka harga saham perusahaan tersebut menjadi naik dan tingkat return saham atau abnormal return juga meningkat.

Abnormal return saham perusahaan besar memiliki nilai pengembalian yang besar, hal ini disebabkan karena tingkat pertumbuhan perusahaan besar relatif lebih cepat jika dibanding dengan perusahaan kecil. Sehingga investor akan lebih berinvestasi pada perusahaan besar dengan harapan memperoleh selisish keuntungan (abnormal return) yang besar. Perusahaan yang memiliki total asset yang bernilai besar telah mencapai tahap kematangan dalam pengelolaan keuanganya karena pada tahap tersebut arus kas perusahaan telah positif dan dianggap memiliki prospek yang lebih baik dalam jangka waktu yang relatif lama (Setiyono, 2016). Hasil penelitian diatas diperkuat dengan hasil beberapa penelitian berikut (Ulfa, 2011), (Prince et al., 2014), (Daniati dan Suhairi, 2006) dan (Absari, 2010) menunjukan bahwa ukuran perusahaan berpengaruh signifikan terhadap abnormal return. Ukuran perusahaan memiliki pengaruh yang signifikan terhadap abnormal return, dimana semakin besar perusahaan maka akan semakin besar abnormal return saham perusahaan tersebut.

\section{Pengaruh GCG terhadap Pengungkapan CSR}

Salah satu tujuan dilaksanakan GCG adalah untuk mendorong timbulnya kesadaran dan tanggungjawab sosial perusahaan terhadap masyarakat dan lingkungan di sekitar perusahaan sehingga dapat terpelihara kesinambungan usaha dalam jangka Panjang. Perusahaan yang telah melaksanakan GCG dengan baik sudah seharusnya melaksanakan kegiatan CSR sebagai wujud kepedulian perusahaan pada lingkungan sosial dan selanjutnya melakukan pengungkapan CSR dalam laporan tahunan. Perusahaan dan investor yang memahami pentingnya GCG lebih mudah menerima adanya kebutuhan dan kewajiban untuk melaksanakan CSR karena kedua kegiatan tersebut berlandaskan pemahaman kaidah yang sama. GCG berkaitan erat dengan tanggungjawab perusahaan kepada pihak-pihak lain yang berkepentingan terutama atas kegiatan ekonomi dan dampaknya, sedangkan CSR berkaitan dengan kegiatan yang diselenggarakan perusahaan untuk menaikkan kesejahteraan masyarakat di luar kegiatan utama perusahaan. Kedua kegiatan tersebut bertujuan untuk mengoptimalkan value perusahaan bagi investor, kreditor dan pemangku kepentingan lainnya (Zarkasyi, 2008). Semua hal tersebut akan terlaksana dengan baik apabila perusahaan menerapkan GCG perusahaan slalu mengembangkan kebijakan untuk menuntun pelaksanaan CSR. perusahaan yang telah melaksanakan GCG dengan baik akan menjalankan CSR secara mandetory, asumsi ini akan menjamin tercapainya maksimalisasi laba dan mempertahankan daya saing perusahaan (Solihin,2011). Hasil penelitian ini sejalan dengan penelitian terdahulu yang telah melakukan penelitian adanya pengaruh positif GCG terhadap pengungkapan CSR yaitu (Nasir \& Abdullah, 2004), (Rosmasita, 2007).

Penerapan GCG serta pengungkapan CSR merupakan konsep yang diajukan demi peningkatan kinerja perusahaan agar meningkatnya value added perusahaan Apabila konsep ini diterapkan maka diharapkan kinerja keuangan yang dilakukan perusahaan akan makin baik dan nantinya menguntungkan pihak investor, kreditor, dan pihak lainnya (Agoes, 2009). Adanya pengungkapan CSR dapat meningkatkan kepercayaan pihak yang berkepentingan terhadap perusahaan (stakeholder), jika banyak pihak yang percaya dan respect terhadap perusahaan, maka secara kontinue dapat meningkatkan value added perusahaan. GCG dan pengungkapan CSR yang baik akan membuat perusahaan melakukan kinerja yang baik sehingga mempengaruhi kinerja keuangan pada perusahaan. kinerja keuangan yang diakibatkan dari perilaku positif dari perusahaan akan memberi dampak pada harga pasar saham yang meningkat, hal ini mengindikasikan bahwa investor atau stakeholder akan memperoleh return atau abnormal return yang tinggi. 


\section{Pengaruh GCG terhadap Abnormal return}

GCG dapat membuat pemegang saham memiliki posisi kuat untuk mengendalikan manajemen secara efektif sehingga dapat membatasi perilaku kesempatan dari manajer. Semakin besar GCG tersebut, semakin besar dan penerapan prinsip transparansi GCG berpengaruh dan keterlibatan investor terhadap kinerja perusahaan yang dapat meningkatkan tingkat pengembalian. Di sisi lain, GCG dapat meningkatkan kualitas saham melalui fungsi monitoring atas pelaporan keuangan dan kesadaran akan pentingnya sistem GCG terhadap peningkatan kualitas nilai perusahaan yang sangat tinggi menyebabkan keyakinan yang tinggi bagi investor. Konsep yang melandasi prinsip dari GCG yaitu Independency dan accountability, dimana dengan adanya pengawasan pada GCG menyebabkan terjadinya beberapa tindakan penyimpangan yang dilakukan oleh pemilik saham agak rendah. Pengelolaan GCG yang sesuai dengan prinsip akan membuat investor lebih percaya dalam penanaman modalnya sehingga investor berharap tingkat pengembalian atau selisih pengembailan semakin tinggi (Nining,2014). Hasil penelitian ini didukung oleh beberapa peneliti diantarnya (Sofilda dan Subaedi, 2006), (Pranata, 2007), (Wardani, 2008) menjelaskan adanya pengaruh positif dan signifikan antara GCG dengan Abnormal return yang menggunakan proksi CGFI sebagai pengukuran kinerja GCG. Penilaian CGPI banyak diikuti oleh perusahaan-perusahaan, karena penilaian tersebut akan berdampak reaksi dari investor dan penilaian CGPI akan dijadikan sebagai salah satu indikator yang akan selalu menjadi pegangan investor dalam penilaian GCG perusahaan (Almilia dan Sifa, 2006, dengan adanya indeks ini akan dapat mempengaruhi kepercayaan investor yang diikuti dengan perubahan harga saham perusahaan, return, dan selisih tingkat pengembalian yang tinggi. Penelitian GCG pada abnormal return dilakukan oleh (Tjondro dan Wilopo, 2011) yang menyatakan bahwa CGPI berpengaruh terhadap abnormal return. Semakin baik skor CGPI maka akan semakin meningkat return saham perusahaan tersebut.

\section{Pengaruh profitabiltas, Ukuran perusahaan, GCG melalui Pengungkapan CSR terhadap Abnormal return.}

Hasil penelitian ini menunjukan bahwa pengungkapan CSR sebagai variabel Moderasi tidak dapat mempengaruhi profitabiltas, Ukuran Perusahaan, GCG terhadap Abnormal return. profitabiltas, Ukuran Perusahan, dan GCG merupakan indikator kinerja keuangan, karaketristik perusahaan serta tata Kelola perusahaan yang baik, variable tersebut sangat erat kaitannya dengan abnormal return. Dapat diasumsikan jika semakin baik pengaruh profitabiltas, ukuran perusahaan, serta GCG dalam penentuan besarnya abnormal return maka perusahaan, akan memperoleh tingkat kepercayaan yang tinggi dari investor dan hal tersebut dapat memberikan kesempatan perusahaan untuk berkembang sehingga dapat meningkatkan harga dan jumlah saham yang beredar di pasar. Meningkatnya harga saham diharapkan agar nantinya tingkat pengembalian kepada investor semakin tinggi. Kepercayaan masyarakat serta investor dapat dibentuk dengan cara program CSR dan pengungkapannya.

Teori stakeholder menjelaskan jika perusahaan dengan profitabiltas tinggi dapat mencerminkan kinerja keuangan perusahaan yang baik dan asset yang dimiliki perusahaan semakin besar sehingga berdampak pada meningkatnya harapan stakeholder akan tingkat pengembalian perusahaan terhadap pengungkapan CSR. Perusahaan yang menyampaikan berita baik (good news) terkait kinerja keuangan perusahaan yang dilihat dari profitabiltas kepada investor diharapkan dapat menjadi sinyal positif terhadap tingkat return ataupun abnormal return investasi yang ditangkap oleh stakeholder, sehingga berdampak pada kenaikan harga saham perusahaan. Hal ini mendukung penelitian (Dewa \& Utaminingsih,2014) serta (Imron, et al,2016) dimana pengungkapan CSR tidak mampu memperkuat hubungan antara ROE terhadap Abnormal return. Berbeda dengan hasil penelitian (Pratama \& Mustanda,2016), (Anindita \& Yuliati,2017) menunjukkan bahwa pengungkapkan CSR sebagai variabel pemoderasi terbukti berpengaruh positif terhadap profitabiltas.

Ukuran perusahaan yang semakin besar maka kewajiban perusahaan dalam melakukan pengungkapan CSR juga akan semakin besar. Oleh karena itu, perusahaan diharapkan mampu mengungkapkan program CSR sebaik-baiknya agar upaya peningkatan citra positif dan memperoleh legitimasi sosial dari para stakeholders (Wulandari dan Wiksuana,2017). Semakin besar ukuran perusahaan maka semakin besar juga tekanan dan tanggungjawabnya terhadap stakeholders dan pemegang saham lainnya, ketika perusahaan melakukan pengungkapan CSR sebagai bentuk tanggungjawab sosialnya maka keberlangsungan perusahaan dapat terjaga dan investor akan semakin tertarik untuk berinvestasi (Pratama dan Mustanda, 2016).

Pengungkapan CSR tidak mampu memperkuat hubungan antaran GCG terhadap abnormal return. Hal ini menunjukkan bahwa survei yang dilakukan IICG tidak menjamin bahwa GCG dan pengungkapan CSR dapat meningkatkan abnormal return. Hal ini dapat disebabkan karen, pengungkapan CSR belum mampu menarik minat investor untuk menanamkan modalnya. CSR berpen.garuh nega.tif signi.fikan pada abnormal 
return perusahaan. Hasil ini didukung dengan hasil penelitian (Reverte,2009), (Purwanto,2011), (Kristi, 2012), (Sari,2012), (Amalia,2013), (Aslan dan Sigal,2016), (Solikhah dan Winarsih 2016) yang menyatakan bahwa pengungkapan CSR tidak mampu memperkuat hubungan antara GCG dan abnormal return.

\section{KESIMPULAN}

\subsection{Kesimpulan}

Penelitian ini bertujuan untuk menguji dan mendapatkan hasil secara empiris tentang pengaruh profitabilitas, ukuran perusahaan, GCG terhadap pengungkapan CSR dan dampaknya terhadap abnormal return. Berdasarkan pengolahan data yang telah dilakukan, diperoleh hasil kesimpulan sebagai berikut:

1) Hipotesis pertama menjelaskan bahwa hasil pengujian yang menjelaskan bahwa profitabilitas berpengaruh signifikan terhadap Abnormal Return dan hasil pengaruh profitabilitas terhadap abnormal return diterima. Hasil pengujian menunjukan bahwa nilai standardized coefficients beta yang positif membuktikan bahwa ada pengaruh antara profitabilitas dengan Abnormal Return. Ini berarti bahwa semakin tinggi profitabilitas yang diperoleh oleh perusahaan akan mempengaruhi tingkat pengembalian abnormal return yang tinggi juga. Hal ini dapat dikatakan bahwa investor tertarik menjadikan profitabilitas sebagai salah satu alasan untuk investor menanamkan modal diperusahaan.

2) Hipotesis kedua menjelaskan bahwa hasil pengujian menjelaskan bahwa profitabilitas berpengaruh signifikan terhadap pengungkapan CSR dan hasil dari pengaruh profitabilitas terhadap Pengungkapan CSR diterima. Hasil pengujian dengan nilai standardized coefficients beta yang positif dan signifikansi membuktikan bahwa ada pengaruh antara profitabilitas dengan CSR. Semakin tinggi nilai profitabilitas yang dihasilkan perusahaan akan mempengaruhi tingkat pengungkapan CSR yang akan dilakukan perusahaan. Pengungkapan digunakan oleh para manajer perusahaan kepada para investor dan untuk membantu mendukung keberlanjutan dan kompensasi manajemen.

3) Hipotesis ketiga menjelaskan bahwa hasil pengujian diatas menjelaskan bahwa ukuran perusahaan berpengaruh signifikan terhadap pengungkapan CSR serta hasil hipotesis dari penelitian ini diterima. Hasil pengujian dengan nilai standardized coefficients Beta yang positif dan signifikansi membuktikan bahwa adanya pengaruh antara Ukuran Perusahaan dengan CSR. Dapat diartikan bahwa semakin besar ukuran perusahaan maka perusahaan tersebut akan semakin luas pegungkapan CSR perusahaan. Pengaruh ukuran perusahaan terhadap pengungkapan CSR tercermin dalam teori legitimasi yang menjelaskan bahwa perusahaan besar mempunyai tingkat legalitas yang tinggi serta tanggungjawab yang besar kepada masyarakat, sehingga pengungkapkan informasi akan lebih banyak dibanding perusahaan kecil.

4) Hipotesis keempat menjelaskan bahwa Ukuran Perusahaan berpengaruh signifikan terhadap Abnormal Return serta hasil hipotesis dari penelitian ini diterima. Hasil pengujian dengan nilai standardized coefficients beta yang positif dan signifikansi membuktikan bahwa adanya pengaruh antara ukuran perusahaan dengan Abnormal Return. Semakin besar ukuran perusahaan diharapkan akan memberikan sinyal kepada investor untuk melakukan invesatsi modal, sehingga secara tidak langsung akan meningkatkan harga saham perusahaan yang berdampak pada tingkat pengembalian abnormal return yang tinggi juga. Salah satu pertumbuhan perusahan dapat dilihat dari besar kecilnya ukuran perusahaan. Besarnya aset yang dimiliki oleh perusahaan jika dikelola dengan baik oleh perusahaan untuk kegiatan operasional perusahaan, maka akan dapat menghasilkan laba besar. Laba yang maksimal akan membuat harga saham meningkat.

5) Hipotesis kelima menjelaskan bahwa hasil pengujian diatas menjelaskan bahwa GCG berpengaruh signifikan terhadap pengungkapan CSR serta hasil hipotesis dari penelitian ini diterima. Hasil pengujian dengan nilai standardized coefficients beta yang positif dan signifikansi membuktikan bahwa adanya pengaruh antara GCG dengan CSR. Hal ini dapat diartikan bahwa semakin baik GCG yang diterapkan perusahaan maka semakin luas dalam pengungkapan CSR. Penerapan GCG serta pengungkapan CSR merupakan konsep yang diajukan demi peningkatan kinerja perusahaan agar meningkatnya value added perusahaan Apabila konsep ini diterapkan maka diharapkan kinerja keuangan yang dilakukan perusahaan akan makin baik dan nantinya menguntungkan pihak investor, kreditor, dan pihak lainnya

6) Hipotesis keenam menjelaskan bahwa hasil pengujian diatas menjelaskan bahwa GCG berpengaruh signifikan terhadap abnormal return serta hasil hipotesis dari penelitian ini diterima. Hasil pengujian dengan nilai standardized coefficients beta yang positif dan signifikansi membuktikan bahwa ada pengaruh antara GCG dengan Abnormal Return. Dapat diartikan bahwa, 
penerapan GCG yang baik akan memberikan sinyal kepada investor untuk menginvestasikan modal kepada perusahaan sehingga akan mempengaruhi tingkat abnormal return yang diperoleh. GCG berhubungan dengan kepercayaan masyarakat terhadap perusahaan. Penerapan GCG pada perusahaan dapat memberikan perlindungan kepada para investor. Investor akan merasa aman atas investasinya, karena cenderung memperoleh return atau abnormal return yang sesuai dengan harapannya.

7) Hipotesis ketujuh menjelaskan bahwa hasil pengujian diatas menjelaskan bahwa profitabilitas, ukuran perusahaan, GCG melalui pengungkapan CSR terhadap abnormal return lebih berpengaruh secara langsung. Hal ini disebabkan karena nilai thitung lebih kecil dari ttable. Penyebab tidak adanya pengaruh secara tidak langsung disebabkan karena pengungkapan CSR sebagai variabel moderasi menjelaskan jika pengungkapan CSR tidak berdampak secara tidak langsung pada profitabilitas, ukuran perusahaan, GCG terhadap abnormal return. Hasil dari penelitian ini menjelaskan bahwa pengungkapan CSR tidak dapat berpengaruh secara tidak langsung, kemungkinan disebabkan adanya jaminan bagi perusahaan yang tercantum pada UU PT No.40 tahun 2007, bahwa perusahaan secara wajib harus melaksanakan CSR dan mengungkapkannya, apabila perusahaan tidak melaksanakan pengungkapan CSR, maka perusahaan tersebut akan terkena sanksi/ denda sesuai dengan ketentuan perundang-undangan

\subsection{Implikasi Penelitian}

Berdasarkan hasil penelitian yang telah dilakukan, terdapat beberapa implikasi yang diberikan kepada bebarapa pihak, yaitu:

1) Hasil dari penelitian ini diharapkan dapat memberikan sumbangan yang berarti dalam pengembangan ilmu akuntansi, khususnya pada bidang teori portofolio dan analisis investasi. Hasil penelitian ini juga diharapkan dapat menjadi bahan referensi dan perbandingan untuk penelitian selanjutnya yang berkaitan dengan pengungkapan tanggung jawab sosial perusahaan maupun Abnormal return.

2) Hasil penelitian ini diharapkan dapat digunakan sebagai referensi untuk pengambilan kebijakan oleh manajemen perusahaan mengenai pengaruh profitabilitas, ukuran perusahaan, GCG, serta pengungkapan CSR dalam laporan keuangan yang disajikan dan pengaruhnya terhadap Abnormal return.
3) Penelitian ini diharapkan dapat memberikan gambaran tentang pengungkapan CSR dalam laporan tahunan sehingga dijadikan sebagai acuan untuk pembuatan keputusan investasi. Penelitian ini diharapkan akan memberikan wacana baru dalam mempertimbangkan aspek-aspek yang perlu diperhitungkan dalam investasi yang tidak terpaku pada ukuran-ukuran moneter.

4) Penelitian ini diharapkan dapat memberikan stimulus sebagai pengontrol atas perilaku-perilaku perusahaan. Selain itu, diharapkan dapat meningkatkan kesadaran masyarakat akan hakhak yang harus diperoleh.

\subsection{Keterbatasan penelitian}

Keterbatasan serta kelemahan dalam penelitian ini bisa mengakibatkan hasil penelitian yang kurang sempurna, sehingga diharapakan peneliti selanjutnya agar dapat disempurnakan. Beberapa keterbatasan dan kelemahan dalam penelitian ini sebagai berikut:

1) Sampel yang digunakan perusahaan LQ 45 yang secara tepat sejumlah 45 perusahaan di tahun 2020 .

2) Kondisi covid-19 menyebabkan nilai abnormal return yang semakin kecil.

3) Penghitungan variabel pengungkapan CSR dan indeks GCG dengan skala 1 untuk perusahaan yang melakukan pengungkapan dan 0 untuk perusahaan yang tidak melakukan pengungkapan.

\subsection{Saran}

Saran yang dapat peneliti berikan dalam penelitian ini berdasarkan hasil penelitian dan pembahasan adalah sebagai berikut:

1) Bagi peneliti selanjutnya agar dapat menambah jumlah sampel ataupun jenis perusahaan dapat diganti dengan jenis perusahaan yang berpengaruh dengan variable peneliti.

2) Bagi peneliti selanjutnya agar dapat menggunakan perameter pengukuran untuk variabel ukuran perusahaan dengan likuiditas.

\section{REFERENSI}

Abdullah, N. (2013). Pengaruh Profitabilitas, Struktur Aktiva, Dan Pertumbuhan Penjualan Terhadap Harga Saham Dengan Struktur Modal Sebagai Variabel Intervening Pada Perusahaan Manufaktur Di Bursa Efek Indonesia. Jurnal Nominal No 1, II.

Agus, P. (2007). Pengaruh Tipe Industri, Ukuran Perusahaan, Profitabilitas, Terhadap Corporate Social Responsiblity. 15, 12-29.

Ahmed, S. U., Islam, M. Z., \& Hasan., d. I. (2012). Corporate Social Responsibility and Financial 
Performance Linkage-evidence from the Banking Sector of Bangladesh. HATAM publisher : Journal of Organizational Management 1(1), 14-21.

Amran, A., \& S. Susela, D. (2008). The Impact Of Government And Foreign Affiliate Influence On Corporate Social Reporting (The Case Of Malaysia). Accounting, Auditing and Accountability Journal, Vol. 23 No. 4., 386404.

Anggara, F. (2010). Faktor-faktor yang Mempengaruhi Pengungkapan Corporate Social Responsibility (CSR) dalam Laporan TahunanPerusahaan (Studi Empiris pada Perusahaan Manufaktur yang Terdaftar dalam Bursa Efek Indonesia). Skripsi. Semarang: Universitas Diponegoro.

Anggraini, R. (2006). Pengungkapan Informasi Sosial dan Faktor-Faktor yang Mempengaruhi Pengungkapan Informasi Sosial dalam Laporan Keuangan Tahunan (Studi Empiris pada Perusahaan-Perusahaan yang Terdaftar Bursa Efek Jakarta). Simposium Nasional Akuntansi 9, Padang.

Astuti, N. (2015). PENGARUH PENGUNGKAPAN CORPORATE SOCIAL RESPONSIBILITY TERHADAP REAKSI PASAR. Dinamika Akuntansi, Keuangan Dan Perbankan, 4(2), 90-105.

Baron, D. (2005). Corporate Social Responsibility and Social Entrepreneurship. Research Paper No. 1916: Stanford Graduate School of Business.

Dedman, E., \& W-J, a. L. (2007). Shareholders Wealth Effects of CEO Departures: Evidence from The UK. Annual Meeting 63rd American Finance Association at Washington DC, 3-5.

Dewi, N. P., \& \& Suaryana, I. G. (2015). Pengaruh Profitabilitas dan Kepemilikan Asing pada Pengungkapan Corporate Social Responsibility. E-Jurnal Akuntansi Universitas Udayana, 13.1, 84-98.

Dwi, O., \& Diah, N. (2014). Hubungan struktur kepemilikan pada pengungkapan tanggungjawab sosial perusahaan publik indonesia. 03, 1-16.

Guidry, R. P., \& \& Patten, D. M. (2010). Market reactions to the first-time issuance of corporate sustainability reports: Evidence that quality matters. Sustainability Accounting, Management and Policy Journal, 1(1), 33-50.

Guthrie, J. P., \& dkk. (2004). Using Content Analysis as a Research Method to Inquire Into Intellectual Capital Reporting. Journal Of Intellectual Capital Vol. 5, No.2., , pp. 289.

Hartono, V. H., \& dkk. (2011). Faktor-faktor yang Mempengaruhi Pengungkapan Tanggung Jawab Sosial dan Dampaknya terhadap Kinerja Keuangan dan ukuran Perusahaan. Fokus Ekonomi (April), 50-68.

Haruman, \& Tendi. (2008). Pengaruh Struktur Kepemilikan terhadap Keputusan Keuangan dan Nilai Perusahaan. Simposium Nasional Akuntansi XI,Pontianak, 23-24 Juli.

Hendarto, K., \& Purwanto, B. (2012). Market Reactions of Mandatory Implementation of Corporate Responsibility: Indonesia Context. . Asia Pasific Management Review 17(4), 379402.

Hillman, A., \& Keim, G. (2001). Shareholder value, stakeholder management, and social issues:What's the bottom line? Strategic Management Journal, 22., 125-139.

Indrawati, N. (2009). Pengungkapan Corporate Social Responsibility (CSR) dalam Annual Report serta Pengaruh Political Visibility dan Economic Performance . Pekbis Jurnal, 1(Maret), 1-11.

Iswanto, H. (2014). PENGARUH CORPORATE SOCIAL RESPONSIBILITY ( CSR ) TERHADAP CITRA ( Survei pada Warga RW 2, Kelurahan Panjang Jiwo , Kecamatan Tenggilis Mejoyo, Kota Surabaya yang Tinggal di Sekitar PT Vitapharm ). 13(1), 1-7.

Jogiyanto. (2009). Teori Portofolio dan Analisis. Yogyakarta: BPFE.

Kamil, A. d., \& dkk. (2012). Pengaruh Karakteristik Perusahaan terhadap luas Pengungkapan Kegiatan Corporate Social Responsibility. Media Riset Akuntansi (Februari), 1-17.

Khaira Amalia Fachrudin. (2011). Analisis Pengaruh Struktur Modal, Ukuran Perusahaan, dan Agency Cost Terhadap Kinerja Perusahaan. Jurnal Akuntansi Dan Keuangan, 13, 37-46. https://doi.org/10.9744/jak.13.1.37-46 
Khoiriah;, M. (2020). Pengaruh Sebelum Dan Saat Adanya Pandemi Covid-19 Terhadap Saham Lq45 Di Bursa Efek Indonesia Tahun 2020. 09(11), 117-126.

Kornel, M. (2016). Perbandingan Abnormal Return Dan Likuditas Saham Sebelum Dan Sedudah Stock Split : Studi Pada. Xx(02), 254-266.

Kurnia S. (2012). Pengaruh Good Corporate Governance Terhadap Harga Saham (Studi Pada Perusahaan Manufaktur Yang Terdaftar Di Bursa Efek Indonesia). Jurnal Ilmiah Akuntansi, 2.

Linzzy P. (2015). Pengaruh Profitabilitas Terhadap Harga Saham Pada Perusahaan Pertambangan Batubara Di Indonesia. Jurnal Ilmiah Manajemen Dan Bisnis Vol. 16, No. 02, 16(02), 49-59.

Nasir, M. N., \& Abdullah, S. (2004). Voluntary Disclosure And Corporate Governance Among Financially Distressed Firms In Malaysia. Financial Reporting, Regulation And Governance, 3.

Nina, I., \& Barus, E. (2016). Pengaruh Gcg Terhadap Kinerja Keuangan Dengan Csr Sebagai Pemoderasi Di Perusahaan Pertambangan. 5(1), 479-488.

Ni Nyoman, Y. (2011). Faktor-Faktor Yang Mempengaruhi Corporate Social Responsibility (Studi Empiris Pada Perusahaan Yang Terdaftar Di Bursa Efek Indonesia Tahun 2009). Tesis. Denpasar: Universitas Udayana.

Nurdin, \& Cahyandito, \&. (2006). Pengungkapan Tema-Tema Sosial Dan Lingkungan Dalam Laporan Tahunan Perusahaan Terhadap Reaksi Investor. Pustaka Ilmiah Universitas Padjajaran.

Nurlela, R., \& Islahuddin. (2008). Pengaruh Corporate Social Responsibility Terhadap Nilai Perusahaan Dengan Prosentase Kepemilikan Manajemensebagai Variabel Moderating. Simposium Nasional Akuntansi Xi, Pontianak, 23-24 Juli.

Nuswandari, C. (2009). Pengaruh Corporate Governance Perception Index Terhadap Kinerja Perusahaan Pada Perusahaan Yang Terdaftar Di Bursa Efek Jakarta. . Jurnal Bisnis Dan Ekonomi. September 2009, Hal. 70-84.
Nuzula, N. F., \& Kato, M. (2010). Do The Japanese Capital Markets Respond To The Publication Of Csr Report. Journal Of Accounting, 1(1).

Oktariani, N. W., Putu, N., \& Harta, S. (2014). Pengaruh Karakteristik Perusahaan Dan Tanggung Jawab Lingkungan Pada Pengungkapan Tanggung Jawab Sosial Perusahaan. 3, 402-418.

O'dowyer. (2003). Conceptions Of Corporate Social Responsibility: The Nature Managerial Capture. Accounting, Auditing, And Accountability Journal 16, 523-557.

Prasetyorini, B. F. (2013). Bhekti Fitri Prasetyorini;Yorini; Pengaruh Ukuran Perusahaan ... 183 Jurnal Imu Manajemen | Volume 1 Nomor 1 Januari 2013 Pengaruh Ukuran Perusahaan, Leverage, Price Earning Ratio Dan Profitabilitas Terhadap Nilai Perusahaan. 1.

Pratinah, D., \& Kusuma., P. A. (2012). Pengaruh Return On Investment (Roi), Earning Per Share (Eps), Dan Deviden Per Share (Dps) Terhadap Harga Saham Perusahaan Pertambangan Yang Terdaftar Di Bursa Efek Indonesia (Bei) 2008-2011. Journal Nominal 1(1), 50-64.

Ratmono, D. (2015). Pengungkapan Corporate Social Responsibility (Csr) Sebagai Sarana Legitimasi: Dampaknya Terhadap Tingkat Agresivitas Pajak. Jurnal Nominal No 2, Iv, 16-30.

Rokhlinasari, S. (2006). Teori- Teori Dalam Pengungkapan Informasi Corporate Social Responsibilty Perbankan. 11.

Raar, J. (2004). Environmental And Social Responsibility : A Normative Financial Reporting Concept. . Accepted For Presentation At The Fourth Asia Pacific Interdisciplinary Research In Accounting Conference, Singapore.

Rahmi Galuh, R. (2010). . Faktor-Faktor Yang Mempengaruhi Pengungkapan Sosial (Social Disclosure) Dalam Laporan Tahunan Perusahaan (Studi Empiris Pada Perusahaan Manufaktur Di Bursa Efek Indonesia). Skripsi. Semarang: Universitas Diponegoro.

Rashid, A., \& Ibrahim, A. S. (2002). Executive And Management Attitudes Towards Corporate 


\section{Jurnal Akuntansi dan Pajak, 22(01), 2021, 94}

Social Responsibility In Malaysia. Corporate Governance 2, No. 4, 10-16.

Ratnawati, S., \& Triyuwono, \&. I. (2009). Analisa Dampak Pengumuman Dividen Terhadap Return, Variabilitas Tingkat Keuntungan Dan Aktivitas Volume Perdagangan Saham (Studi Peristiwa Pada Perusahaan Manufaktur Di Bej). Wacana, 12(4): H:712-724.

Reddy, K., \& Gordon, L. W. (2010). The Effect Of Sustainability Reporting On Financial Performance: An Empirical Study Using Listed Companies. Journal of Asia Entrepreneurship And Sustainability, 6(2)., 1945.

Rosmasita. (2007). Faktor-Faktor Yang Mempengaruhi Pengungkapan Sosial (Social Disclosure) Dalam Laporan Keuangan Tahunan Perusahaan Manufaktur Di Bursa Efek Jakarta. Simposium Nasional Akuntansi X, Makasar.

Rute, A. D., \& Crowther, D. (2005). Corporate Social Responsibility In Portugal: Epirical Evidence Of Corporate Behaviour. Corporate Governance 5, 3-18.

Said, R. Z., \& Haron, H. (2009). The Ralationship Between Corporate Social Responsibility Disclosure And Corporate Governance Characteristics In Malaysian Public Listed Companies. Social Responsibility Journal, 5, 212-226.

Sari, R. A. (2012). Pengaruh Karakteristik Perusahaan Terhadap Corporate Social Responsibility Disclosure Pada Perusahaan Manufaktur Yang Terdaftar Di Bursa Efek Indonesia. Jurnal Nominal Volume I Nomor I, 124-140.

Sembiring, E. (2006). Karakteristik Perusahaan Dan Pengungkapan Tanggung Jawab Sosial: Study Empiris Pada Perusahaan Yang Tercatat Di Bursa Efek Jakarta. Jurnal Magister Akuntansi, Vol. 6 Januari.
Sembiring, E. R. (2005). Karakteristik Perusahaan Dan Pengungkapan Tanggung Jawab Sosial: Studi Empiris Pada Perusahaan Yang Tercatat Di Bursa Efek Jakarta. Simposium Nasional Akuntansi 8 Solo.

Setiyono, E. (2016). Pengaruh Kinerja Keuangan Dan Ukuran Perusahaan Terhadap Return Saham. 5.

uganda, T. R. (2018). Teori Dan Pembahasan Reaksi Pasar Modal Indonesia. Malang: Cv. Seribu Bintang.

Wahyudi, U., \& Pawestri, H. P. (2006). Implikasi Struktur Kepemilikan Terhadap Nilai Perusahaan: Dengan Keputusan Keuangan Sebagai Variabel Intervening. . Simposium Nasional Akuntansi Ix, Padang, 23-26 Agustus.

Wijaya, K. D. (2005). Riset Keuangan, Pengujian Empiris. Jakarta: Gramedia.

Xu, E. A. (2011). Stock Market's Reaction To Disclosure of Enviromental Violation: Evidence From China. Journal Of Business Ethics, No. 107, 227-237. 